\title{
Observations on Nine Peach Rootstocks grown in a Replant Soil
}

\author{
D. Remorini a, C. Fei, F. Loreti and R. Massai \\ Department of Agriculture, Food and Environment, University of Pisa, Italy \\ ${ }^{a}$ Corresponding author: damiano.remorini@unipi.it
}

Keywords: Prunus persica, soil sickness, winter and summer pruning, trunk crosssectional area, yield efficiency, cumulative yield, fruit quality.

\begin{abstract}
'Flavorcrest' peach [Prunus persica (L.) Batsch] trees grafted onto nine rootstocks (four hybrids of peach, almond and $P$. davidiana: Barrier 1, Cadaman, GF 677, and Sirio; five plum clones: Ishtara, Julior, Mr.S.2/5, Penta and Puebla) were grown in a replant soil in the Pisa Province (Italy). Trees were planted on January 1998 at $4.5 \times 2.0 \mathrm{~m}$ spacing and trained to a free spindle ('fusetto'). Measurements of the vegetative growth, yield, phenology and fruit quality of each tree were recorded annually. Results of trunk cross-sectional area, size and volume of the canopy, summer and winter pruning weights showed that Barrier 1, GF 677 and Cadaman were the most vigorous rootstocks followed by plum clones and then Sirio. Sirio and plum clones had earlier harvest times compared to the other rootstocks; whereas fruit ripening on GF 677 and Barrier 1 was delayed. Cumulative yield was highest on Cadaman and GF 677 and lowest on Penta, Sirio and Mr.S. 2/5, while yield efficiency was highest on Sirio, Julior, Puebla, Cadaman and Ishtara. Fruit size was highest on Barrier 1, GF 677 and Ishtara and lowest on Julior and Sirio. Flesh firmness was highest on vigorous rootstocks (Barrier 1, Cadaman and GF 677) while a lower soluble solids content was found only on Barrier 1 rootstock. Finally, there was a higher mortality rate, for Ishtara, Julior and Sirio, due to replant disease.
\end{abstract}

\section{INTRODUCTION}

Soil sickness is a serious problem, known for many years, related to the practice of replanting of fruit tree crops. These symptoms commonly occur for some important species such as apple, peach, cherry, apricot, grape, citrus, poplar, etc. (Yadava and Doud, 1980). Soil sickness has been related to the lack of nutrient availability, soil compaction, accumulation of phytotoxic compounds from root exudation or decay and with the presence of soil pathogen (Gur and Cohen, 1989; Utkhede and Smith, 1994; Benizri et al., 2005; Bent et al., 2009; Alonso and Espada, 2011; Yang et al., 2012).

To overcome this problem, the means commonly used today are to sterilise the soil through the use of fumigants with a wide action spectrum, solarisation (Tanner et al., 2006), and the adoption of rootstocks resistant to replant disease (Neilsen and Yorston, 1991; Jimenez et al., 2011; Orazem et al., 2011a; Orazem et al., 2011b). The lack of knowledge of the predominant cause of this "sickness" and of the mechanism that induces resistance in some rootstocks leads, however, to a high level of uncertainty and of variability in the results when these remedies are adopted. Finally, the need to limit to the necessary minimum the use of chemicals in agriculture, for the purpose of increasing the 
sustainability of farming, has strongly limited the use of fumigants in recent years, making the use of suitable rootstocks ever more important.

In recent years many new rootstocks obtained from interspecific crosses, roughly recognised as peach $\mathrm{x}$ almond or plum clones, have been introduced in Europe and little information on their resistance to soil sickness or replant problems has been available until now (Reighard, 2002; Loreti and Massai, 2006; Reighard and Loreti, 2008).

This study reports data of eight consecutive years of a comparison test between nine rootstocks grown on a replant soil in the Pisa area (Italy) where we have previously reported some preliminary observations (Massai and Loreti, 2004).

\section{MATERIALS AND METHODS}

'Flavorcrest' peach [Prunus persica (L.) Batsch] trees grafted onto nine rootstocks (four hybrids of peach, almond and P. davidiana: Barrier 1, Cadaman, GF 677, and Sirio; five plum clones: Ishtara, Julior, Mr.S.2/5, Penta and Puebla) were grown in a replant soil in the Pisa Province (Italy). The replant site was, previously a peach orchard on peach seedlings, managed with grassed row middles and herbicide strips along the row that was uprooted when it was 15 years old. For each grafting combination, 25 plants subdivided into 5 replications of 5 plants each were used. Trees were planted in January 1998 at $4.5 \mathrm{x}$ $2.0 \mathrm{~m}$ spacing, and trained to a free spindle ('fusetto'), in the same rows of the previous planting in order to increase the effect of the "sickness" symptoms and managed with superficial tillage during the spring-summer period to eliminate the presence of weeds. At the same farm there was also a bioagronomic evaluation trial of peach rootstocks in progress, planted in virgin soil, in which 4 of the rootstocks mentioned were present, which was used as the control. All years fruits were harvested at \pm 7 days of standard commercial stage for 'Flavorcrest' cultivar.

For simplicity's sake, the rootstocks belonging genetically to the $P$. persica $\times$. dulcis (GF 677, Sirio) crosses are indicated in the text as 'PxA' (peach $\mathrm{x}$ almond), the $P$. persica $\times$ P. davidiana (Barrier 1 and Cadaman) crosses are indicated in the text as " 'PxD' (peach $\mathrm{x}$ davidiana) and those obtained by clonal selection or interspecific hybridisation of plum (Adesoto, Ishtara-Ferciana, Mr.S. 2/5, Julior-Ferdor and Penta) are indicated as 'PCH' (Plum Clone Hybrid).

During the first 3 years of growth, all of the main vegetative, productive and phenologic parameters were measured on all trees in the trial, as well as the mortality rate, while fruit quality parameters were measured on 10 fruits per tree.

In particular, the parameters measured were: summer and winter pruning weight $\left(\mathrm{kg} /\right.$ tree), trunk cross-sectional area $20 \mathrm{~cm}$ above the grafting point $\left(\mathrm{TCSA}, \mathrm{cm}^{2}\right.$ ), production per tree $(\mathrm{kg} / \mathrm{tree})$ mean fruit weight $(\mathrm{g})$, flesh firmness $(\mathrm{FF}, \mathrm{kg})$ and soluble solids content (SSC, ${ }^{\circ}$ Brix). The data were subjected to one-way analysis of variance (ANOVA). The averages were separated by means of tests of the Least Significant Difference (LSD) for $\mathrm{p}=0.05$.

\section{RESULTS AND DISCUSSION}

Mortality rate of the trees at the end of the third year after planting was low, never exceeding $20 \%$ in the worst case (i.e., Ishtara, Table 1). The best adapted rootstocks to the replant conditions were Adesoto (no tree lost) and GF 677, Barrier 1 and Cadaman (8\% mortality), which were characterized as medium-high vigour. The rootstocks with the highest mortality rates were Ishtara-Ferciana (20\%), Sirio and Julior-Ferdor (16\%) 
characterized by low-medium vigour. These mortality rates are lower than those reported by other authors (Jimenez et al., 2011) but similar or higher than some other experiments (Font i Forcada et al., 2012).

The differences between rootstocks are greater if we take into consideration the amount of wood removed annually through summer and winter pruning (Fig. 1). On average during the eight years, medium-high vigour rootstocks (GF 677, Barrier 1, Cadaman) were subjected to pruning of $8.2 \mathrm{~kg} / \mathrm{tree} / \mathrm{yr}$ while, for medium-low vigour $\mathrm{PCH}$ clones, PW was of approximately $5.8 \mathrm{~kg} / \mathrm{tree} / \mathrm{yr}$ and only $4.3 \mathrm{~kg} / \mathrm{tree} / \mathrm{yr}$ for the least vigorous rootstock, Sirio.

According to pruning data, the vegetative growth of the trees, expressed as TCSA (Fig. 2) showed a considerable influence of the vigour of rootstock after few years of growth. TCSA higher than $160 \mathrm{~cm}^{-2}$ were recorded for the high vigour group composed of GF 677, Barrier 1 and Cadaman (respectively 181, 186 and $160 \mathrm{~cm}^{-2}$ ) in which the latter was statistically less developed than the other two by $8 \%$. A second group composed of all the $\mathrm{PCH}$ rootstocks were less vigorous by approximately $20 \%$ with respect to the first group. Sirio had a TCSA equal to approximately $45 \%$ of the GF 677 and PxD clones. Yield efficiency values (mean yield/TCSA, Fig. 2) show higher values for lowest vigour rootstock (Sirio) and lowest values for higher vigour rootstocks (Barrier 1 and GF 677). These data confirm the results of Alonso and Espada (2011) and Jiménez et al (2011) where higher vigour rootstock induced lowest yield efficiency. In addition, cumulative yield is correlated whit vigour and not correlated with genetic origin of rootstocks. Cadaman had the highest cumulative yield $(101 \mathrm{~kg})$ while the lowest yield was recorded for Mr.S.2/5 rootstock (56 kg). Barrier 1, GF 677 and Ishtara had higher mean fruit values compared to Julior, Mr.S.2/5, Penta and Sirio rootstocks (Fig. 3). Flesh firmness and SSC were also influenced by rootstock (Fig. 4). Barrier 1 produced the firmest fruits, confirming delayed maturity induced by this clone (Remorini et. al., 2008; Orazem et al., 2011b), while Julior and Sirio had higher values for SSC.

\section{CONCLUSIONS}

Results described confirm the importance of the growth rate and genetic origin of the rootstock used in overcoming stress from replanting.

The consolidated tendency to use, mainly in Europe, GF 677 in peach replanting appears validated by the set of experimental data resulting from this trial. Nevertheless, this result is in contrast with other (Jimenez et al., 2011; Orazem et al., 2011a) where GF677 is not considered the best resistant rootstock. However, next to the peach $\mathrm{x}$ almond hybrid, other rootstocks show equally satisfying, if not actually better, behaviour. In particular, the two peach $\mathrm{x} P$. davidiana hybrids, Barrier 1 and Cadaman, showed reduced or negligible plant mortality, good vegetative growth and the trees started producing earlier and with high mean fruit weight, thus showing their reliability in replant situations in place of GF 677. Furthermore, it is important to remember the effect of Barrier 1 rootstock on the bud break, blooming and ripening times, which occur approx. 5-7 days later with respect to other subjects. Cadaman also had a highly satisfactory behaviour comparable to that of GF 677 both in terms of growth and in terms of induced productivity.

Furthermore, the above-mentioned rootstocks were also characterised by less variability in the vegetative and productive parameters with respect to the plum rootstocks. The latter were more sensitive to replant conditions, showing lower vegetative growth, lower productivity and high variability in behaviour, but they had generally a 
higher yield efficiency. Among these, Ishtara and Penta appear better at this time because of the lower variability and fairly good canopy development, even though they were considerably smaller than the PxA rootstocks and their mortality rates were higher.

In summary, the results described confirm the importance of the growth rate in overcoming stress from replanting.

\section{ACKNOWLEDGEMENTS}

Research work supported by the MiPAF Targeted Project: "Fruitculture", Subproject "Rootstocks Breeding".

\section{Literature Cited}

Alonso, J.M. and Espada, J.L. 2011. Influence of the rootstock on the agronomic performance of 'Jesca' peach under replant conditions. Acta Hort. 903: 489-493.

Benizri, E., Piutti, S., Verger, S., Pagès, L., Vercambre, G., Poessel, J.L. and Michelot, P. 2005. Replant diseases: Bacterial community structure and diversity in peach rhizosphere as determined by metabolic and genetic fingerprinting. Soil Biol. Biochem. 37(9): 1738-1746.

Bent, E., Loffredo, A., Yang, J.-I., McKenry, M.V., Becker, J.O. and Borneman, J. 2009. Investigations into peach seedling stunting caused by a replant soil. FEMS Microb. Ecol, 68(2): 192-200.

Font i Forcada, C., Gogorcena, Y. and Moreno, M.A. 2012. Agronomical and fruit quality traits of two peach cultivars on peach-almond hybrid rootstocks growing on Mediterranean conditions. Sci. Hort. 140: 157-163.

Gur, A. and Cohen, Y. 1989. The peach replant problem-some causal agents. Soil Biol. and Biochem. 21(6): 829-834.

Jiménez, S., Pinochet, J., Romero, J., Gogorcena, Y., Moreno, M.A. and Espada, J.L. 2011. Performance of peach and plum based rootstocks of different vigour on a late peach cultivar in replant and calcareous conditions. Sci Hort. 129(1): 58-63.

Loreti, F. and Massai, R. 2006. State of the art on peach rootstocks and orchard systems. Acta Hort. 713: 253-268.

Massai, R. and Loreti, F. 2004. Preliminary observations on nine peach rootstocks grown in a replant soil. Acta Hort. 658: 185-192.

Neilsen, G.H. and Yorston, J. 1991. Soil disinfection and monoammonium Phosphate fertilization increase precocity of apples on replant problems soils. J. Amer. Soc. Hort. Sci. 118: 50-53.

Orazem, P., Stampar, F. and Hudina, M. 2011a. Comparison of Ten Peach Rootstocks Performance Grafted with 'Redhaven'. Europ. J. Hort. Sci. 76: 162-169.

Orazem, P., Stampar, F. and Hudina, M. 2011b. Quality analysis of 'Redhaven' peach fruit grafted on 11 rootstocks of different genetic origin in a replant soil. Food Chemistry 124(4): 1691-1698.

Reighard, G.L. 2002. Current directions of peach rootstock programs worldwide. Acta Hort. 592: 421-427.

Reighard, G.L. and Loreti, F. 2008. Rootstock development. p. 193-220. In: D.R. Layne and D. Bassi (eds.), The Peach. CABI, Wallingford, Oxfordshire, UK.

Remorini, D., Tavarini, S., Degl'Innocenti, E., Loreti, F., Massai, R. and Guidi, L. 2008. Effect of rootstocks and harvesting time on the nutritional quality of peel and flesh of peach fruits. Food Chem. 110(2): 361-367. 
Utkhede, R.S. and Smith, E.M. 1994. Biotic and abiotic causes of replant problems of fruit trees. Acta Hort. 363: 25-32.

Yadava, U.L. and Dould, S.L. 1980. The short life and replant problems of deciduous fruit trees. Hort. Rev. 2: 1-116.

Tanner, S.C., Reighard, G.L. and Wells, C.E. 2006. Soil treatments differentially affect peach tree root development and demography in a replant site. Acta Hort. 713: 381387.

Yang J.-i., Ruegger P.M., McKenry M.V., Becker J.O. and Borneman J. 2012. Correlations between Root-Associated Microorganisms and Peach Replant Disease Symptoms in a California Soil. PLoS ONE 7(10): e46420. 


\section{Tables}

Table 1. List of rootstocks tested on a replant soil in Colignola (Pisa, Italy), their genetic origin and country of selection. Mortality rate of the trees at the end of the third year after planting is also reported.

\begin{tabular}{|c|c|c|c|}
\hline Rootstocks tested & Genetic origin & $\begin{array}{l}\text { Country of } \\
\text { selection }\end{array}$ & $\begin{array}{c}\text { Mortality rate } \\
(\%)\end{array}$ \\
\hline $\begin{array}{l}\text { Adesoto-101 } \\
\text { Puebla }\end{array}$ & Prunus insititia & Spain & 0 \\
\hline Barrier 1 & P. persica $x$ P. davidiana & Italy & 8 \\
\hline Cadaman-Avimag & P. persica $\times$ P. davidiana & $\begin{array}{c}\text { France } \\
\text { (Hungary) }\end{array}$ & 8 \\
\hline GF 677 & P. persica $\times P$. dulcis & France & 8 \\
\hline Ishtara-Ferciana & $\begin{array}{c}\text { (P. cerasifera } x \text { P. salicina) } x \\
(P . \text { cerasifera } x P \text {. persica })\end{array}$ & France & 20 \\
\hline Julior-Ferdor & P. insititia $x$ P. domestica & France & 16 \\
\hline Mr.S.2/5 & Open poll. of $P$. cerasifera & Italy & 12 \\
\hline Penta & $\begin{array}{c}\text { Open poll. of Imperial } \\
\text { Epineuse }(P . \text { domestica })\end{array}$ & Italy & 12 \\
\hline Sirio & $\begin{array}{l}\text { Open poll. of GF } 557 \\
\text { (P. persica } \times \text { P. dulcis) }\end{array}$ & Italy & 16 \\
\hline
\end{tabular}




\section{Figures}

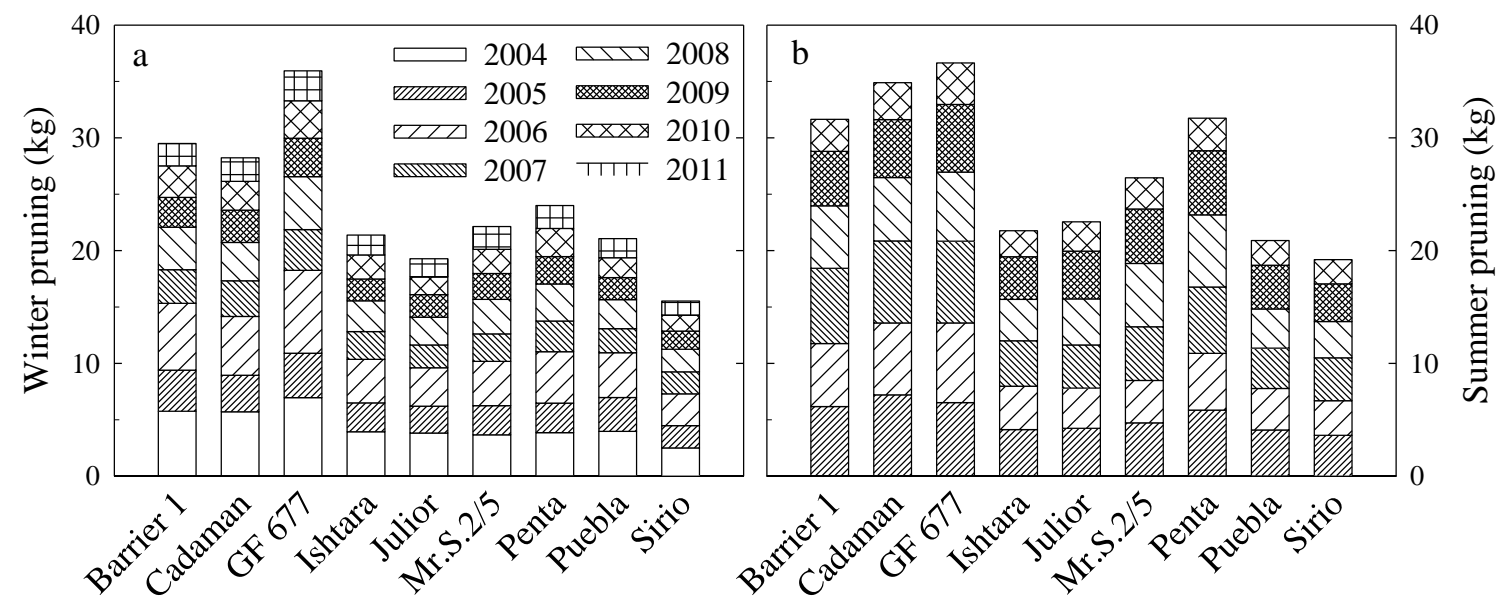

Rootstock

Figure 1. Winter (a) and summer (b) pruning weight of Flavorcrest trees grafted onto nine rootstocks and planted in a replant soil in Colignola (Pisa, Italy).

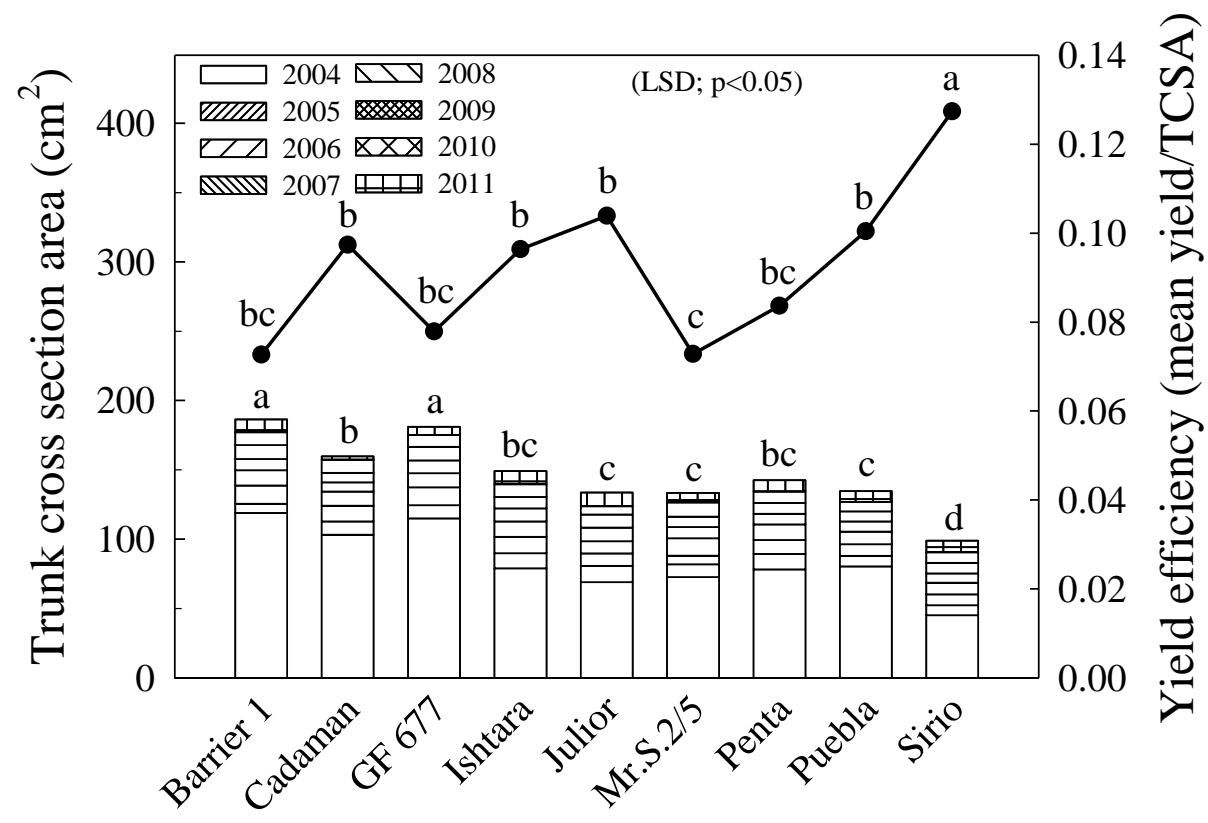

\section{Rootstock}

Figure 2. Trunk cross-sectional area (left; bars) and yield efficiency (right; line) of cv. Flavorcrest grafted onto nine rootstocks and planted in a replant soil in Colignola (Pisa, Italy). Means with different letters are significantly different from each other $(\mathrm{P}<0.05)$. 


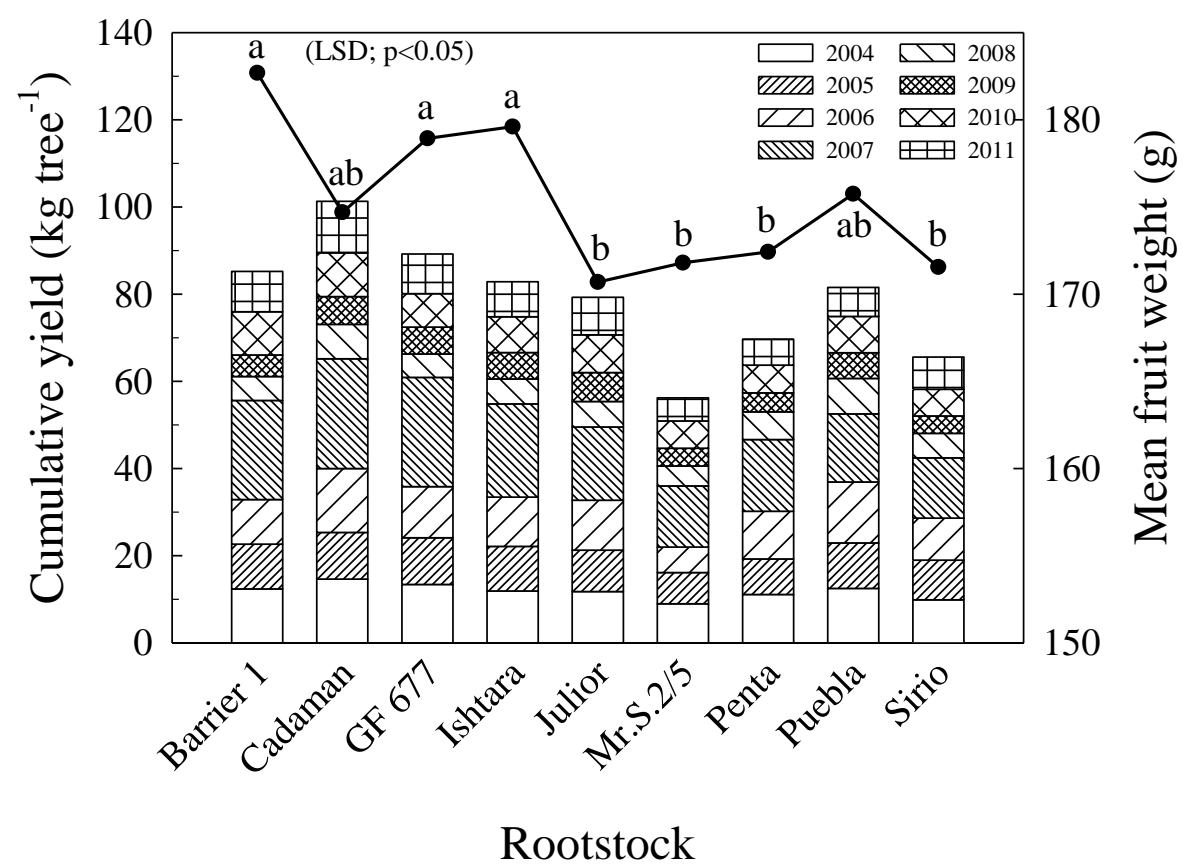

Figure 3. Cumulative yield (left; bars) and mean fruit weight (right; line) of cv. Flavorcrest grafted onto nine rootstocks and planted in a replant soil in Colignola (Pisa, Italy). Means with different letters are significantly different from each other $(\mathrm{P}<0.05)$.

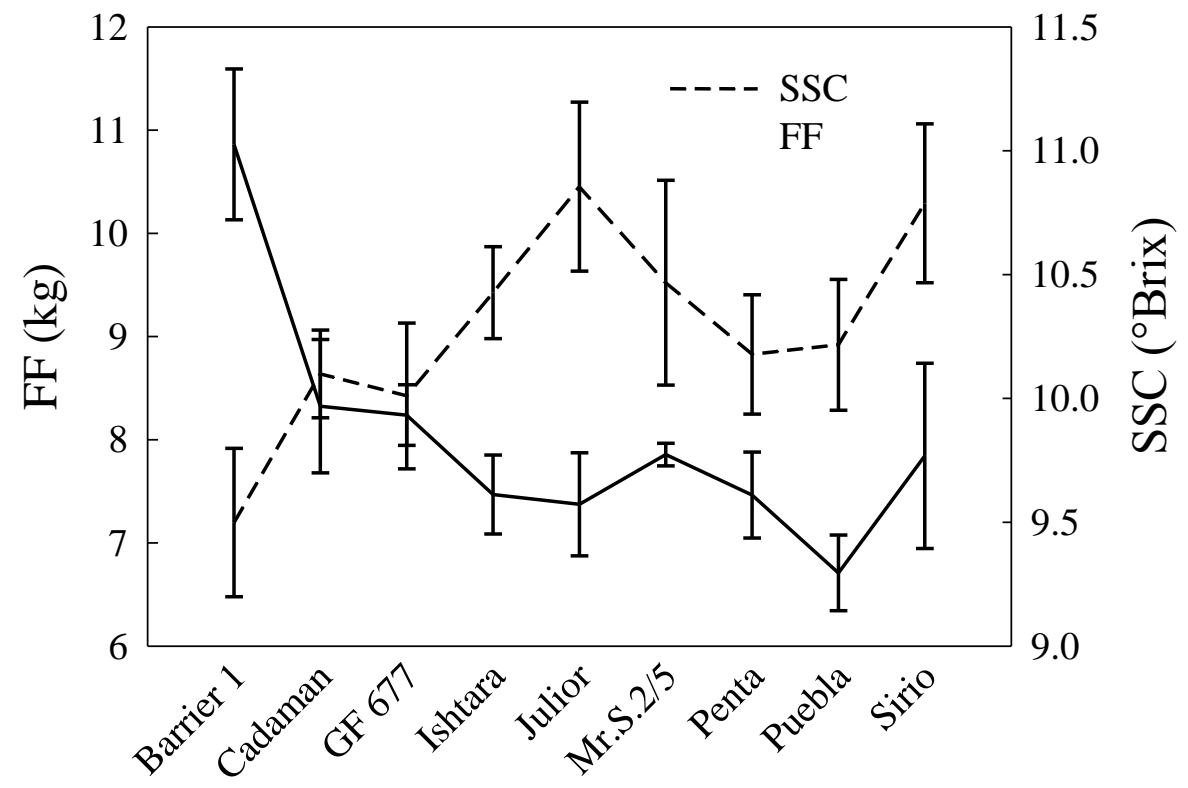

\section{Rootstock}

Figure 4. Flesh firmness (FF) and soluble solids content (SSC) of cv. Flavorcrest grafted onto nine rootstocks and planted in a replant soil in Colignola (Pisa, Italy). Data are mean of 8 consecutive years (2004-2011). Bars represent standard error. 